\title{
NRTSC
}

NUCLEAR REACTOR TECHNOLOGY

AND SCIENTIFIC COMPUTATIONS

Keywords: salety rod s-rods

experiments garnma heating LOCA

PTERM

CAMEL

Retention - Permanent

\section{TENSILE AND BURST TESTS IN SUPPORT OF THE CADMIUM SAFETY ROD FAILURE EVALUATION (U)}

\section{By}

J. K. Thomas

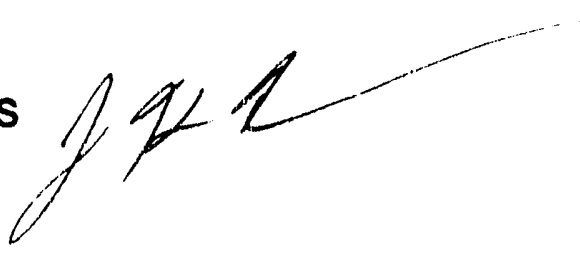

ISSUED: February 1992

\section{MASTER}

$$
\frac{\text { G.C. Keo } 3-18-92}{\text { Derivative Classifier }}
$$

DISTRIBUTION OF THIS DOCUMENT IS UNLIMITED

SRL SAVANNAH RIVER LABORATORY, AIKEN, SC 29808 
PROJECT: REACTOR COMPONENTS RESPONSE TO GAMMA HEATING ACCIDENT

DOCUMENT: WSRC-RP-92-314

TITLE: TENSILE AND BURST TESTS IN SUPPORT OF THE CADMIUM SAFETY ROD FAILURE EVALUATION (U)

TASK: $\quad 91-001-1$

APPROVALS
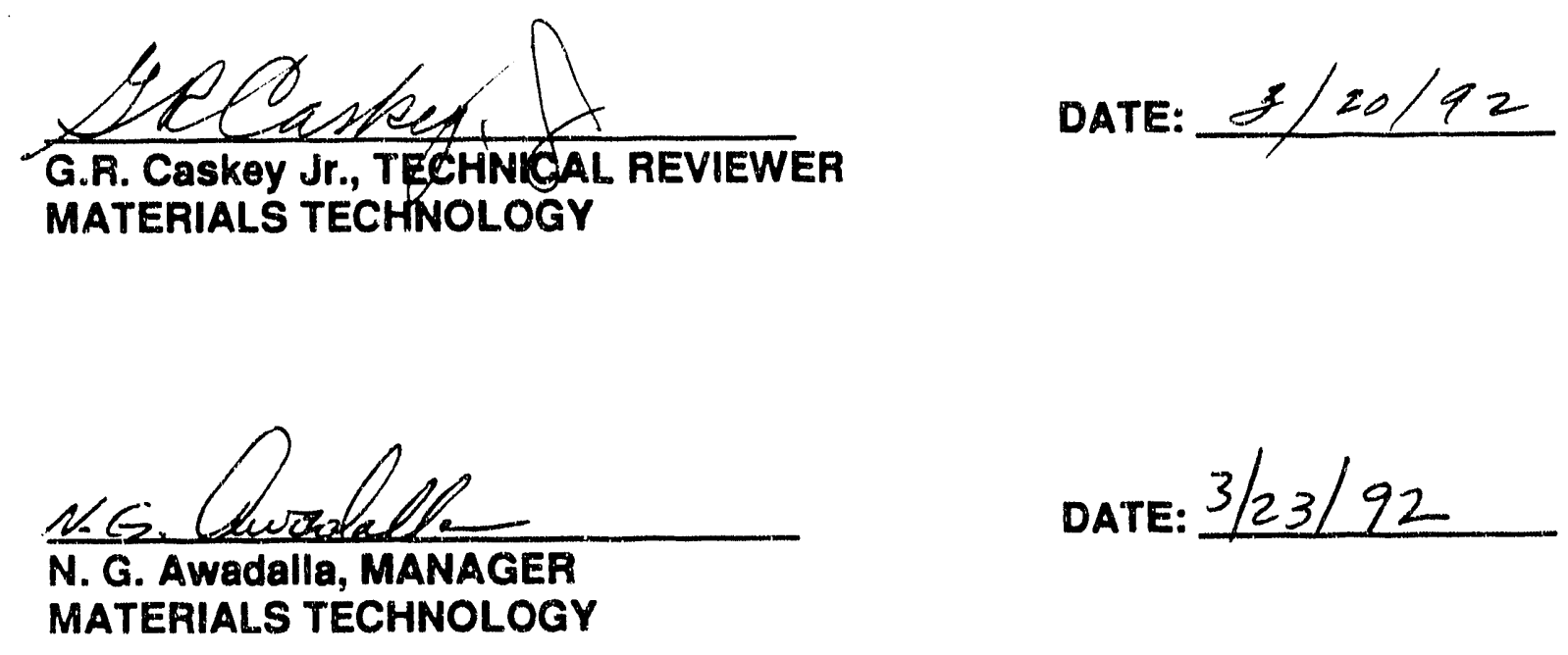

DATE: $3 / 23 / 92$

MATERIALS TECHNOLOGY

DATE: $3 / 23 / 42$

T. L. Capoletti, MANAGER

MATERIALS TECHNOLOGY 


\section{EXECUTIVE SUMMARY}

The reactor safety rods may be subjected to high temperatures due to gamma heating after the core coolant level has dropped during the ECS phase of a hypothetical LOCA event. Accordingly, an experimental safety rod testing subtask was established as part of a task to address the response of reactor core components to this accident. This report discusses confirmatory separate effects tests conducted to support the evaluation of failures observed in the safety rod thermal tests.

As part of the failure evaluation, the potential for liquid metal embrittlement (LME) of the safety rod cladding by cadmium (Cd) - aluminum (Al) solutions was examined. Based on the test conditions, literature data, and U-Bend tests, it was concluded that the SS304 safety rod cladding would not be subject to $\mathrm{LME}$ by liquid $\mathrm{Cd}-\mathrm{Al}$ solutions under conditions relevant to the safety rod thermal tests or gamma heating accident. To confirm this conclusion, tensile tests on SS304 specimens were performed in both air and liquid $\mathrm{Cd}-\mathrm{Al}$ solutions with the range of strain rates, temperatures, and loading conditions spanning the range relevant to the safety rod thermal tests and gamma heating accident. No reduction in ductility or strength was observed for the tensile tests in $\mathrm{Cd}-\mathrm{Al}$ or $\mathrm{Cd}$ liquid metal solutions relative to the tests in air; therefore, the results of the tensile tests demonstrate that neither Cd nor Cd-Al mixtures embrittle SS304 under the conditions relevant to this evaluation. The tensile tests also illustrated the effect of temperature and strain rate of the presence and magnitude of serrations in the SS304 stress-strain curve. The decrease in the ductility of SS304 associated with the slow strain rates was also demonstrated.

The safety rod cladding ductility (e.g. hoop strain at failure) was also examined as part of the failure analysis. In order to confirm the estimated cladding ductility and to illustrate the nature of a pure mechanical cladding failure (e.g. overpressure), pressurized tube tests were performed on safety rod cladding samples. A pressurized tube burst test demonstrated that the safety rod cladding has good $550^{\circ} \mathrm{C}$ ductility under high strain rate biaxial loading conditions and that the methcdology employed in this task to predict failure strains for cold-worked SS304 under biaxial loading conditions is reasonable. A second pressurized tube test demonstrated that the safety rod cladding could withstand at least $80 \%$ of the burst pressure for 6 hours and that little or no creep deformation would be accumulated over this period. 


\section{TABLE OF CONTENTS}

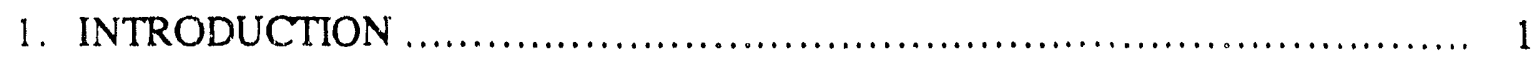

2. TENSILE TESTS ........................................................... 3

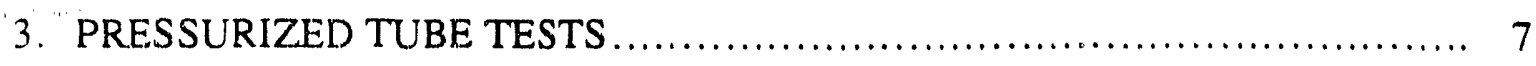

4. CONCLUSION S ............................................................... 9

5. REFERENCES .......................................................... 10

ATTACHMENT A: WSTC TEST REPORT ................................. 19

ATTACHMENT B: WORKSCOPE FOR WSTC TESTS ........................... 24

\section{LIST OF TABLES}

1 Tensile Test Data............................................................................ 11

\section{LIST OF FIGURES}

1 Safety Rod Cross Section. ...................................................... 12

2 Strength Data (2" gauge length, $0.35 "$ dia.).................................. 13

3 Ductility Data (2" gauge length, $0.35 "$ dia.)................................ 14

4 Comparison of Tensile Properties in Liquid Metal and in Air....................... 15

5 Load-Displacement Curve for Tensile Test in Air at $500^{\circ} \mathrm{C}$ and $3 \mathrm{E}-3 \mathrm{~min}^{-1} \ldots \ldots \ldots \ldots 16$

6 Load-Displacement Curve for Tensile Test in Air at $550^{\circ} \mathrm{C}$ and $3 \mathrm{E}-3 \mathrm{~min}^{-1} \ldots \ldots \ldots \ldots 17$

7 Load-Displacement Curve for Tensile Test in Air at $600^{\circ} \mathrm{C}$ and $3 \mathrm{E}-3 \mathrm{~min}^{-1} \ldots \ldots \ldots \ldots 18$ 


\section{INTRODUCTION}

The reactor safety rods may be subjected to high temperatures due to gamma heating after the core coolant level has dropped during the ECS phase of a hypothetical LOCA event. Accordingly, an experirnental safety rod testing subtask was established as part of a task to address the response of reactor core components to this accident (Thomas 1991). The experimental subtask compliments the structural evaluation (finite elemen analysis) of the safety rod (Gupta 1991). This report discusses confirmatory separate effects tests conducted to support the evaluation of failures observed in the safety rod thennal tests.

The active, or cadmium (Cd) bearing, portion of the safety rod consists of a $0.756^{\prime \prime}$ diameter aluminum alloy (Al-6061) core, a 0.05" thick Cd layer, and a 0.042" thick Type 304 stainless steel cladding. A cross section of the safety rod is shown in Figure 1. As part of the manufacturing process, a thin ( $\approx 1$ mil) nickel $(\mathrm{Ni})$ flash coating was applied to the Al-6061 core to aid in Cd application, and the stainless steel cladding was swaged from 1 " to 0.94 " outer diameter so as to contact the C.d layer.

The safety rod thermal tests are described in Thomas et al. (1991). These tests consisted of subjecting safety rod segments to elevated temperatures to determine their time-temperature failure threshold. The peak temperature, rate of temperature increase, and hold time at the peak temperature were test variables. Twenty-five tests were conducted using specimens taken from 4 different safety rods at maximum test temperatures between 500 and $900^{\circ} \mathrm{C}$. Five failures occurred via rupture of the stainless steel cladding. Three of the failures occurred at maximum temperatures between 521 and $590^{\circ} \mathrm{C}$; these failures occurred with specimens taken from a single safety rod in tests using a slow thermal ramp rate $\left(\approx 4^{\circ} \mathrm{C} / \mathrm{min}\right)$. The other two failures occurred above $830^{\circ} \mathrm{C}$; these failures occurred with specimens taken from two separate safety rods using a fast thermal ramp rate (> $100^{\circ} \mathrm{C} / \mathrm{min}$ ). No failures occurred below $521^{\circ} \mathrm{C}$.

The examination of failed specimens and failure evaluation are discussed in Thomas et al. (1992). As part of the failure evaluation, the potential for liquid metal embrittlement (LME) of the safety rod cladding by cadmium (Cd) - aluminum ( $\mathrm{Al}$ ) solutions was examined. Based on the test conditions, literature data, and U-bend tests, it was concluded that the SS304 safety rod cladding would not be subject to LME by liquid $\mathrm{Cd}$-Al solutions under conditions relevant to the safety rod thermal tests or gamma heating accident. To confirm 
this conclusion, tensile tests on SS304 specimens were performed in both air and liquid $\mathrm{Cd}-\mathrm{Al}$ solutions. The tensile tests are discussed in Section 2.

The safety rod cladding ductility (e.g. hoop strain at failure) was also examined as part of the failure analysis. Sufficient literature data was available to estimate the cladding failure strain considering the effects of cladding temperature, strain rate, cold work, and biaxial loading. In order to confirm the estimated cladding ductility and to illustrate the nature of a pure mechanical failure (e.g. overpiessure) for the cladding, pressurized tube tests were performed on safety rod cladding samples. These tests are discussed in Section 3.

The conclusions from the tensile and pressurized tube tests are presented in Section 4.

These tests were conducted at the Westinghouse Science and Technology Center (WSTC). They were considered scoping in nature and were not carried out under an NRTSC technical procedure; however, the NRTSC experimental QA procedure guidelines were employed where possible. Per NRTSC QAP III-2, the data from these tests do not require qualification for critical applications since they were confirmatory in nature and were not the sole basis for the conclusions reached in the failure evaluation concerning safety rod cladding ductility and LME susceptibility.

Attachment $A$ is the WSTC report which describes these tests and presents the experimental results. The test data, photographs of the experimental rigs, specimen manufacture information, and calibration data are filed with the task records. The workscope for these tests is given as Attachment B; the workscope is part of Interworks Requisition 964720897742 (J.A. Begley, Westinghouse Science and Technology Center, Pittsburgh, PA). 


\section{TENSILE TESTS}

The tensile tests were performed to examine the susceptibility of SS304 to liquid metal embrittlement (LME) by $\mathrm{Cd}$ and $\mathrm{Cd}-\mathrm{Al}$ solutions under conditions (strain rate \& temperature) relevant to the safety rod thermal tests and gamma heating accident. The results from the U-bend tests and literature review (Thomas et al. 1992) indicated that this systern would not be susceptible to LME under these conditions.

The experimental conditions and results are summarized in Table 1. The "fast" strain rate $\left(3 \times 10^{-3} \mathrm{~min}^{-1}\right)$ bounds the highest strain rate expected for the temperature ramp rates predicted for the garnma heating accident. Susceptibility to LME generally increases with increasing strain rate (Thomas et al. 1992). The calculations performed to date for the gamma heating accident indicate that at least 30 minutes is required to reach peak safety rod temperatures less than $600^{\circ} \mathrm{C}$ (Cooper and Taylor 1991). The highest measured hoop strain for specimens tested at or below $600^{\circ} \mathrm{C}$ was $5.5 \%$ (Thomas et al. 1992). Therefore a hoop strain of $6 \%$ and ramp time of 20 minutes were selected as bounding $\left(0.06 / 20=3 \times 10^{-3}\right.$ $\left.\min ^{-1}\right)$. Note that this strain rate is 2 orders of magnitude below the upper end of the LME susceptibility range, $0.6 \mathrm{~min}^{-1}$ (Thomas et al. 1992), and is just below the strain rate range employed in standard tensile tests, $5 \times 10^{-3}$ to $5 \times 10^{-2} \mathrm{~min}^{-1}$ (ASTM Standards E21-79 and E8-88). Fast strain rate tests were conducted over a range of temperatures from 325 to $600^{\circ} \mathrm{C}$. The "slow" strain rate $\left(8 \times 10^{-5} \mathrm{~min}^{-1}\right)$ bounds the lowest strain rate in the safety rod thermal tests. For this purpose, a minimum hoop strain of $1 \%$ over a period of 2 hours was adopted $\left(0.01 / 120=8 \times 10^{-5} \mathrm{~min}^{-1}\right)$. Only one set of air and liquid metal tests at $550^{\circ} \mathrm{C}$ was conducted at this strain rate since it is expected to give lower LME susceptibility. The first two tests listed in Table 1 were conducted to qualify the experimental setup and data acquisition systems, and were conducted with variable strain rates. A single test was conducted in $\mathrm{Cd}-\mathrm{Al}$ at $550^{\circ} \mathrm{C}$ with a strain rate of $9 \times 10^{-4} \mathrm{~min}^{-1}$ as part of the test procedure development.

The notched specimen tests were included to examine the effect of triaxial loading on LME susceptibility. Only one set of air and liquid metal tests at $550^{\circ} \mathrm{C}$ was conducted with notched specimens; all other tests were conducted with smooth tensile specimens. The cross head speed for the notched specimen tests was set to the same value as for the smooth specimens tested at a strain rate of $3 \times 10^{-3} \mathrm{~min}^{-1}$, although the strain rate in the region of the notch would obviously be larger. 
The specimens were machined from mil-annealed SS304 bar stock $0.625^{\prime \prime}$ in diameter. The machined gauge length and diameter were $2.00 "$ and $0.35^{\prime \prime}$, respectively. Note that the applicable ASTM standards (E21-79 and E8-88) call for a gauge length to diameter ratio (L/D) of 4; these specimens have a $5.7 \mathrm{~L} / \mathrm{D}$ ratio. This will tend to decrease the effect of necking on total elongation relative to standard tensile specimens (e.g. will give lower values of total elongation). The notched specimens had a notch diameter of 0.252 " and a notch rooi radius of $0.007 "$. A three-zone furnace was used to heat the specimens, and the test temperature was maintained to within $\pm 2^{\circ} \mathrm{C}$.

The tests in air were conducted to obtain baseline tensile properties. Liquid $\mathrm{Cd}$ with dissolved Al-6061 was employed as the liquid metal solution since this reproduces the conditions in the safety rod thermal tests. A single test at $550^{\circ} \mathrm{C}$ in pure $\mathrm{Cd}$ was conducted for comparison to the $550^{\circ} \mathrm{C}$ test in Cd-Al. The tests in liquid metal were conducted by affixing a stainless steel cup to the bottom tensile grip. The cup was loaded with $35 \mathrm{~g}$ of $\mathrm{Cd}$ and, for the $\mathrm{Cd}-\mathrm{Al}$ tests, an $\mathrm{Al}-6061$ inner sleeve. The fast strain rate tests $\left(3 \times 10^{-3} \mathrm{~min}^{-1}\right.$ and $9 \times 10^{-4} \mathrm{~min}^{-1}$ ) were conducted with a stainless steel muffle to prevent $\mathrm{Cd}$ loss. The slow strain rate tests $\left(8 \times 10^{-5} \mathrm{~min}^{-1}\right)$ required more effective $\mathrm{Cd}$ retention since they lasted several days, and a stainless steel bellows affixed over the top end of the specimen was employed for these tests.

Table 1 gives the results for the tensile tests. The yield values correspond to a $0.2 \%$ offset on the strain axis. Reduction in Area (RA) values were not available for the specimens tested in liquid metal. The data for the air tests are shown in Figures 2 and 3 along with correlations recommended by Sikka and Booker (1977) for SS304 manufactured in the United States. The $3 \times 10^{-3} \mathrm{~min}^{-1}$ tensile data should be in good agreement with these correlations since strain rate effects would not be expected to play a role. As can be seen in Figure 2, the yield (YS) and ultimate (UTS) strength data from these experiments are significantly higher than the correlations; the YS values are larger by approximately 70 to $85 \%$, and UTS values are larger by 20 to $25 \%$. This is probably due to cold work (CW) introduced by straightening operations on the bar stock. Based on the evaluation of Moen and Duncan (1976), these strength increases correspond to approximately 4 to 6\% CW. The ductility data do not show that same trend; the reduction in area values are in good agreement with the correlation and the total elongation values are approximately $10 \%$ below the correlation, which is expected based on the relatively long gauge length employed in these tests. The stainless steel cladding on the safety rods had $6 \% \mathrm{CW}$ introduced by swaging during manufacture, so that the cold work level in the tensile specimens based on 
the tensile strength data would be roughly equivalent to that in the safety rod cladding. The total elongation at failure for the test conducted at $550^{\circ} \mathrm{C}$ with a strain rate of $8 \times 10^{-5} \mathrm{~min}^{-1}$ should be reduced by approximately $25 \%$ relative to the tests employing a $3 \times 10^{-3} \mathrm{~min}^{-1}$ strain rate (Thomas et al. 1992). Based on the average of the 4 tests conducted with a strain rate of $3 \times 10^{-3} \mathrm{~min}^{-1}(38.9 \%)$ and the 2 tests conducted at $8 \times 10^{-5} \mathrm{~min}^{-1}(30.0 \%)$, the relative decrease was $23 \%$, which is in excellent agreement with the expected value. The relative decrease for the test conducted with a strain rate of $9 \times 10^{-4} \mathrm{~min}^{-1}$ was $4 \%$. The decrease in the $\mathrm{RA}$ value at $550^{\circ} \mathrm{C}$ for a strain rate of $8 \times 10^{-5} \mathrm{~min}^{-1}$ relative to that at $3 \times 10^{-3}$ $\min ^{-1}$ (e.g. $4.2 .2 \%$ vs. $68.7 \%$ ) is consistent with data reported by Swindeman and Brinkman (1982).

The ratio of the total elongation, YS and UTS data for the liquid metal tests to those conducted in air are shown in Figure 4; in computing these ratios, the data were averaged where two or more data points were available for the same test conditions. No reduction in ductility or strength was observed for the tensile tests in $\mathrm{Cd}$-Al liquid metal solution relative to the tests in air for either strain rate employed or with the notched specimens. The loaddisplacement curves for these tests are essentially identical. Therefore, the results of the tensile tests demonstrate that neither Cd nor Cd-Al mixtures embrittle SS304 under the conditions relevant to the safety rod thermal tests or gamma heating accident. This is in agreement with the results from the $U$-bend tests and literature review (Thomas et al. 1992).

The stress-strain (load-displacement) curves for the tests conducted at temperatures above $500^{\circ} \mathrm{C}$ with a strain rate of $3 \times 10^{-3} \mathrm{~min}^{-1}$ are serrated. Serrated flow in austenitic stainless steels in this temperature regime has ixeen widely reported in the literature (Barnby 1965 , Jenkins and Smith 1969, and Ruggles and Krempl 1991) and is discussed in Thomas et al. (1992) as it relates to deformation of the safety rod cladding. Serrated flow is caused by the Portevin-LeChatelier phenomenon and related to dynamic strain aging (Reed-Hill 1973 and Dieter 1976); it has also been referred to as "jerky" flow. Dislocation locking by impurities and precipitates, and the subsequent generation of additional dislocations and/or unlocking of dislocations, causes the stress required for plastic flow (e.g. the flow stress) to increase and decrease sharply, thus introducing serrations to the stress-strain curve. Increased flow stresses and work-hardening rates accompany serrated flow. For austenitic stainless steels at relatively low temperatures, serrated flow is caused by carbon (C) atoms interacting with dislocations; at higher temperatures, $\mathrm{Cr}$ is sufficiently mobile that chromium carbides can precipitate on dislocation lines. At sufficiently high temperatures, 
the precipitates form quickly enough that serrated flow is not observed throughout the range of the stress-strain curve. At even higher temperatures, serrated flow is not observed at all. The severity of the effect and range over which it will be observed is dependent on the diffusion rates for $\mathrm{Cr}$ and $\mathrm{C}$, which are in turn dependent on vacancy concentration. Therefore, cold-worked steel will exhibit serrated flow more severely and at lower temperatures than annealed steel. The serrations observed in these tests are more severe and occur at lower strains than those typically reported for austenitic stainless steels (Barnby 1965 and Jenkins and Smith 1969). Figures 5, 6, and 7 show the loaddisplacment curves for the tests conducted at temperatures of 500,550 and $600^{\circ} \mathrm{C}$ with a strain rate of $3 \times 10^{-3} \mathrm{~min}^{-1}$.

Slow strain rates can also enhance serrated flow since the dislocation line velocity will decrease and hence the required $\mathrm{Cr}$ and $\mathrm{C}$ diffusion rates will decrease; this will decrease the temperature at which serrated flow is observed. Serrated flow was not observed in the test conducted at $550^{\circ} \mathrm{C}$ with a strain rate of $8 \times 10^{-5} \mathrm{~min}^{-1}$. Serrated flow was observed at $550^{\circ} \mathrm{C}$ and $9 \times 10^{-4} \mathrm{~min}^{-1}$, but ceased near the UTS. These observation support the assertion that the range of serrated flow shifts to lower temepratures for slower strain rates. 


\section{PRESSURIZED TUBE TESTS}

Pressurized tube tests were conducted using safety rod cladding samples in order to verify the high-temperature biaxial ductility of the safety rod cladding and demonstrate the nature of an overpressure failure with this material.

Safety rod cladding samples approximately 10 " in length were taken from the non-Cd bearing end of one of the safety rods employed in the safety rod thermal tests; this safety rod is referred to as number 3 in Thomas et al. (1991 and 1992). The measured cladding thickness and diameter were 0.037 " and 0.94 ", respectively, which is in good agreement with the values given in Thomas et al. (1992). Two safety rod cladding samples were tested at a temperature of $550^{\circ} \mathrm{C}$; the test temperature was held to within $\pm 3^{\circ} \mathrm{C}$ over the $6 "$ heated length using a three-zone furnace. The internal pressure was applied using nitrogen gas.

In the first test, the pressure was rapidly increased to failure (tube rupture); the pressure ramp was approximately linear with time. The cladding ruptured at 4200 psi after a 330 sec. pressure ramp time. The hoop strain $(\Delta \mathrm{D} / \mathrm{D})$ at failure was $15.4 \%$ as measured with a clip gauge, while the post-test circumference measurement gave a hoop strain of $16.3 \%$; the clip gauge value was judged to be more reliable since the circumference measurement includes some deformation induced after the rupture occurred. The predicted hoop strain at failure for the test conditions $\left(550^{\circ} \mathrm{C}, 0.03 \mathrm{~min}^{-1}\right.$ avg. strain rate, $6 \%$ cladding cold work and biaxial loading) was 15\% (Thomas et al. 1992), which is in excellent agreement with the experimental value. This test serves to demonstrate the ductility of the cladding and validate the methodology employed to predict failure strain under these conditions.

The hoop stress for thin walled tubing can be expressed as (Rust 1979):

$$
\begin{aligned}
& \sigma_{\emptyset}=\frac{\mathrm{Pr}}{\mathrm{t}} \\
& \text { where: } \begin{aligned}
\sigma_{\emptyset}=\text { Hoop stress, } \\
\mathrm{r}=\text { Cladding radius, and } \\
\mathrm{t}=\text { Cladding thickness. }
\end{aligned}
\end{aligned}
$$

The engineering hoop stress for a pressure load of $4200 \mathrm{psi}$ and the pre-test safety rod cladding dimensions given above $\left(\mathrm{r}=0.940^{\prime \prime} / 2, \mathrm{t}=0.037^{\prime \prime}\right)$ is $53.4 \mathrm{ksi}$, which is $75 \%$ of the $550^{\circ} \mathrm{C}$ UTS value from the fast strain rate tensile tests. The measured post-test cladding 
thickness was 30 mils; assuming no plastic axial strain and using the measured post-test cladding circumference gives a cladding thickness of 31 mils.

The second test consisted of a 6 hour exposure at approximately 3480 psi. ( $83 \%$ of the rupture pressure from the first test). This loading is representative of those calculated for the safety rod thermal test conditions using a finite element model of the safety rod (Gupta 1991), and the test time bounds the maximum temperature exposure period during the safety rod thermal tests (Thomas et al. 1992). The cladding survived the test without rupture. The measured plastic hoop strain was $3.4 \%$.

Very little creep strain was accumulated during the 6 hour hold period. The creep strain was estimated to be less than $0.2 \%$; the plot of diameter vs. time taken from the clip gauge signal lacks sufficient resolution to accurately determine this value. Equation I gives a hoop stress of $48.3 \mathrm{ksi}$ for a pressure load of $3480 \mathrm{psi}$ and the measured post-test dimensions. Using the best estimate creep law for unirradiated SS304 given in Attachment E of Mertz and Thomas (1991), this hoop stress is predicted to result in a creep rate of $9.3 \times 10^{-3} \% / \mathrm{hr}$. The total creep strain accumulated during the test is therefore predicted to be $0.06 \%$, which is approximately a factor of 3 less than the estimated upperbound value based on the experimental data. 


\section{CONCLUSIONS}

No reduction in ductility or strength was observed for the tensile tests in Cd-Al or Cd liquid metal solutions relative to the rests in air. These tests spanned the range of strain rates, temperatures, and loading conditions relevant to the safety rod thermal tests and gamma heating accident. Therefore, the results of the tensile tests derionstrate that neither Cd nor Cd-Al mixtures embrittle SS304 under the conditions relevant to this evaluation. This is in agreement with the results from the U-berd tests and literature review discussed in Thomas et al. (1992). The tensile tests also illustrated the effect of temperature and strain rate of the presence and magnitude of serrations in the stress-strain clirve for SS304. The decrease in ductility associated with the slow strain rate tensile tests $\left(8 \times 10^{-5} \mathrm{~min}^{-1}\right)$ is consistent with the predictions made in Thomas et al. (1992).

The pressurized tube burst test demonstrated that the safety rod cladding has good $550^{\circ} \mathrm{C}$ ductility under high strain rase biaxial loading conditions and that the methodology employed in Thomas et al. (1992) to predict failure strains for col.w-worked SS304 unde: biaxial loading conditions is reasonable. The second pressurized tube test demonstrated that the safety rod cladding could withstand at least $80 \%$ of the burst pressure for 6 hours and that little or no creep deformation would be accumulated over this period. This loading and duration beund those of the safety rod thermal tests and provide further verification that the faiiures observed below $600^{\circ} \mathrm{C}$ were not solely mechanical in nature.

These tests were conducted at the Westinghouse Science and Technology Center. They were considered scoping in nature and were not carried out under an NRTSC technical procedure; however, the NRTSC experimental QA procedure guidelines were employed where possible. Per NRTSC QAP III-2, the data from these tests do not require qualification for critical applications since they were confirmatory in nature and were not the sole basis for the conclusions reached in the failure evaluation concerning and safety rod cladding ductility and LME susceptibility. 


\section{REFERENCES}

Barnby, J.T. (1965) "Effect of Strain Aging on the High-Temperature Tensile Properties of an AISl 316 Austenitic Stainless Steel," LIron and Steel Inst., pp. 392-7.

Cooper, R.E. and J.R. Taylor (1991) "RE: Heat Transfer Data for MTS Gamma Heating Task," NES-CDG-910038, Interoffice Memorandum, Westinghouse Savannah River Co., Aiken, SC, 17 March 1991.

Dieter, G.E. (1976) Mechanical Metallurgy, McGraw-Hill, New York, NY.

Gupta, N.K. (199 i) Summary Report-Reactor Component Response to Gamma Heating Accident - Response of the Safety Rods, WSRC-TR-91-411, Westinghouse Savannah River Co., Aiken, SC, Oct. 1991.

Jenkins, C.F. and G.V. Smith (1969) "Serrated Plastic Flow in Austenitic Stainless Steel," Trans.Met. Soc.AIME, 245: 2149-56.

Mertz, G.E. and J.K. Thomas (1991) Reactor Tank Response to the Gamna Heating Accident, WSRC-TR-91-554, Westinghudse Savannah River Laboratory, Aiken, SC, Nov. 1991.

Moen, R.A. and D.R. Duncan (1976) Cold Work Effects: A Compilation of Data for Types 304 and 316 Stainless Steel, HEDL-TI-76005, Westinghouse Hanford Co., Richland, WA.

Reeú-Hill, R.E. (1973) Physical Metallurgy Principles, 2nd Edition, Brooks/Cole Engineering Div., Monterey, CA.

Ruggles, M.B. and E. Krempl (1991) "Rate Sensitivity and Short-Term Relaxation Behavior of AISI Type 304 Stainless Steel at Room Temperature and at $650^{\circ} \mathrm{C}$; Influence of Prior Aging," L.Press.Vessel Tech. (Trans.ASME), 113: 385-91.

Rust, J.H. (1976) Nuclear Power Plant Engineering, Haralson Putlishing Co., Buchanan, GA, p. 405.

Sikka, V.K. and M.K. Booker (1977) "Assessment of.Tensile and Creep Rupture Data for Types 304 and 316 Stainless Steels," L.Press.Vess.Tech. (Trans.ASME), 298-313.

Swindeman, R.W. and C.R. Brinkman (1982) "Progress in Understanding the Mechanical Behavior of Pressure Vessel Materials at Elevated Temperatures," in Pressure Vessels and Piping Design Technology - 1982 - A Decade of Progress, S.Y. Zamrik, ed., Am.Sor.Mech.Eng. (ASME), New York, NY, pp.153-69.

Thomas, J.K. (1991) "Reactor Components Respense to Gamma Heating Accident," Task 91-001-1 Management/Task Technical Plan, SRL-EDG-90-0002, Interoffice Miemorandum, Westinghouse Savannah River Co., Aiken, SC, 4 Jan. 1991.

Thomas, J.K., N.C. Iyer, H.B. Peacock and D.R. Leader (1991) Qverview of the Safety Rod Laboratory Testing Program, WSRC-TR-91-515, Westinghouse Savannah River Co., Aiken, SC, Sept. 1991.

Thomas, J.K., H.B. Peacock and N.C. Iyer (1992) Examination of Cadmium Safety Rod Thermal Test Specimens and Failure Mechanism Evaluation, WSRC-RP-92-222, Westinghouse Savannah River Co., Aiken, SC, Jan. 1992. 
Table 1 Tensile Test Data.

\begin{tabular}{|c|c|c|c|c|c|c|c|c|c|}
\hline $\begin{array}{c}\text { Spec. } \\
\text { No. }\end{array}$ & $\begin{array}{l}\text { Spec. } \\
\text { Type }\end{array}$ & $\begin{array}{c}\text { Environ- } \\
\text { ment }\end{array}$ & $\begin{array}{l}\text { Strain } \\
\text { Rate } \\
\left(\min ^{-1}\right)\end{array}$ & $\begin{array}{l}\text { Temp. } \\
\left({ }^{\circ} \mathrm{C}\right)\end{array}$ & $\begin{array}{c}\text { Yield } \\
\text { Strength } \\
\text { (ksi) }\end{array}$ & $\begin{array}{c}\text { Ultimate } \\
\text { Strength } \\
\text { (ksi) }\end{array}$ & $\begin{array}{c}\text { Uniform } \\
\text { Elong. } \\
(\%) \text { [a] }\end{array}$ & $\begin{array}{l}\text { Total } \\
\text { Elong. } \\
(\%)[a]\end{array}$ & $\begin{array}{l}\text { R.A. } \\
(\%)\end{array}$ \\
\hline 5 & Sinooth & Air & $2.2 \mathrm{E}-2[\mathrm{~b}]$ & 325 & 36.2 & 76.8 & 34.5 & 41.5 & 70.5 \\
\hline 6 & Smooth & Air & $4.5 \mathrm{e}-3[\mathrm{c}]$ & 325 & 40.2 & 78.6 & 34.5 & 41.5 & 69.6 \\
\hline 17 & Smooth & Air & $3 e-03$ & 32.5 & 41.6 & 79.1 & 33.2 & 39.0 & 69.8 \\
\hline 19 & Smooth & Air & $3 e-03$ & 325 & 41.4 & 79.4 & 33.2 & 39.6 & 70.7 \\
\hline 7 & Smooth & Air & $3 e-03$ & 400 & 34.7 & 76.5 & 35.3 & 42.2 & 70.1 \\
\hline 8 & Smooth & Air & $3 e-03$ & 400 & 38.3 & 78.5 & 35.0 & 38.5 & 69.7 \\
\hline 9 & Sinooth & Air & $3 e-03$ & 500 & 33.5 & 74.6 & 35.0 & 41.1 & 67.5 \\
\hline 10 & Smooth & Air & $3 e-03$ & 500 & 33.2 & 73.8 & 34.8 & 38.5 & 68.0 \\
\hline 12 & Smooth & Air & $3 e-03$ & 550 & 31.3 & 71.3 & 31.0 & 36.3 & 68.8 \\
\hline 14 & Smooth & Air & $3 e-103$ & 550 & 30.8 & 71.4 & 34.3 & 41.5 & 68.6 \\
\hline 15 & Smooth & Air & $3 e-03$ & 600 & 32.4 & 63.1 & 25.3 & 38.3 & 66.2 \\
\hline 16 & Smooth & Air & $3 e-03$ & 600 & 30.6 & 62.1 & 26.0 & 39.2 & 66.9 \\
\hline 38 & Smooth & Air & $8 e-05$ & 550 & 32.2 & 60.8 & 23.6 & 29.8 & 42.2 \\
\hline 2 & Notched & Air & [d] & 550 & 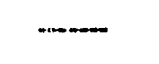 & 91.4 & - & .....- & $\ldots$ \\
\hline 3 & Notched & Air & [d] & 550 & - & 90.3 & - & - & - \\
\hline 20 & Smooth & Cd-Al & $3 e \cdot 03$ & 325 & 37.9 & 78.7 & 36.8 & 41.8 & -- \\
\hline 21 & Smooth & $\mathrm{Cd}-\mathrm{Al}$ & $3 e-03$ & 400 & 37.9 & 77.5 & 35.1 & 38.8 & - \\
\hline 22 & Smooth & $\mathrm{Cd}-\mathrm{Al}$ & $3 e-03$ & 500 & 34.3 & 75.3 & 33.6 & 39.9 & - \\
\hline 13 & Smooth & $\mathrm{Cd}$ & $3 e-03$ & 550 & 33.3 & 70.6 & 30.8 & 38.1 & - \\
\hline 18 & Smooth & $\mathrm{Cd}-\mathrm{Al}$ & $3 e-03$ & 550 & 32.2 & 69.7 & 33.8 & 40.7 & $\ldots$ \\
\hline 23 & Smooth & $\mathrm{Cd}-\mathrm{Al}$ & $3 e-03$ & 600 & 32.2 & 60.3 & 26.2 & 44.3 & - \\
\hline 25 & Smooth & Cd-Al & $9 e-04$ & 550 & 33.3 & 68.7 & 31.2 & 37.7 & - \\
\hline 26 & Smooth & $\mathrm{Cd}-\mathrm{Al}$ & $8 e-05$ & 550 & 33.8 & 61.4 & 24.3 & 30.2 & - \\
\hline 1 & Notched & $\mathrm{Cd}-\mathrm{Al}$ & [d] & 550 & - & 90.6 & - & - & - \\
\hline
\end{tabular}

Ncics: [a] Gauge length $=2 "$, gauge diameter to length ratio $=5.7$.

[b] Dummy test, strain rate $=1.3 \mathrm{E}-4 \mathrm{~min}^{-1}$ to $0.025 \%$ strain, then $2.2 \mathrm{E}-2 \mathrm{~min}^{-1}$.

[c] Dummy test, strain rate $=8.0 \mathrm{E}-3 \mathrm{~min}^{-1}$ to $0.8 \%$ strain, then $4.5 \mathrm{E}-3 \mathrm{~min}^{-1}$.

[d] Crosshead speed as for the smooth bar tests with a strain rate of $3 \mathrm{E}-3 \mathrm{~min}^{-1}$. 


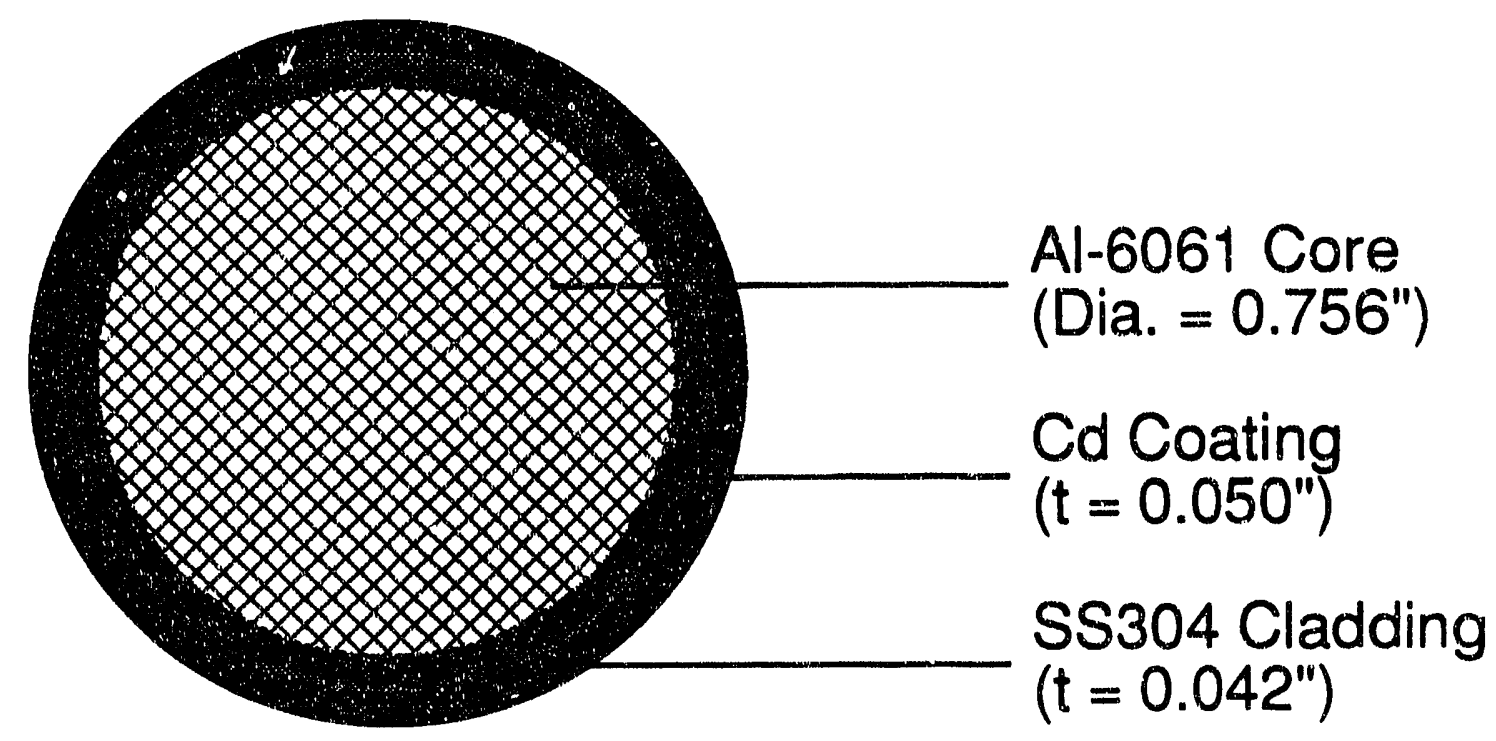

Figure 1 Safety Rod Cross Section. 

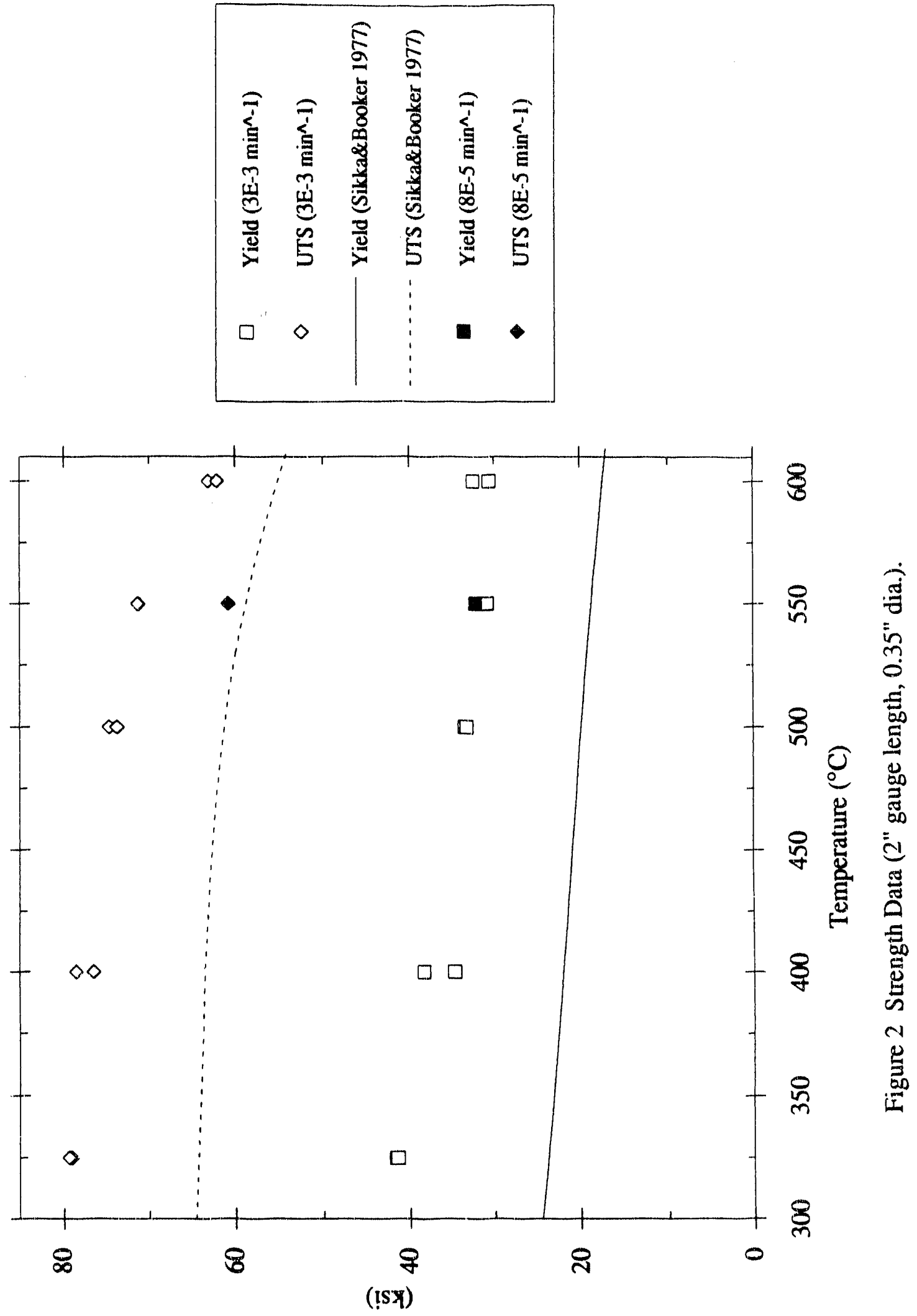


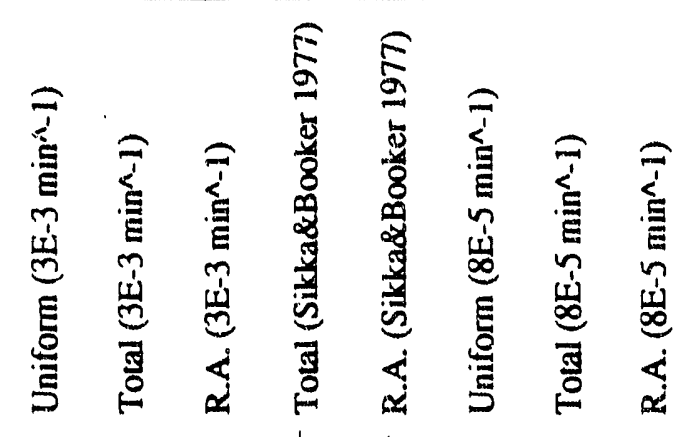

$$
\begin{aligned}
& \begin{array}{ll|l:l} 
& \diamond & & \\
& & &
\end{array}
\end{aligned}
$$

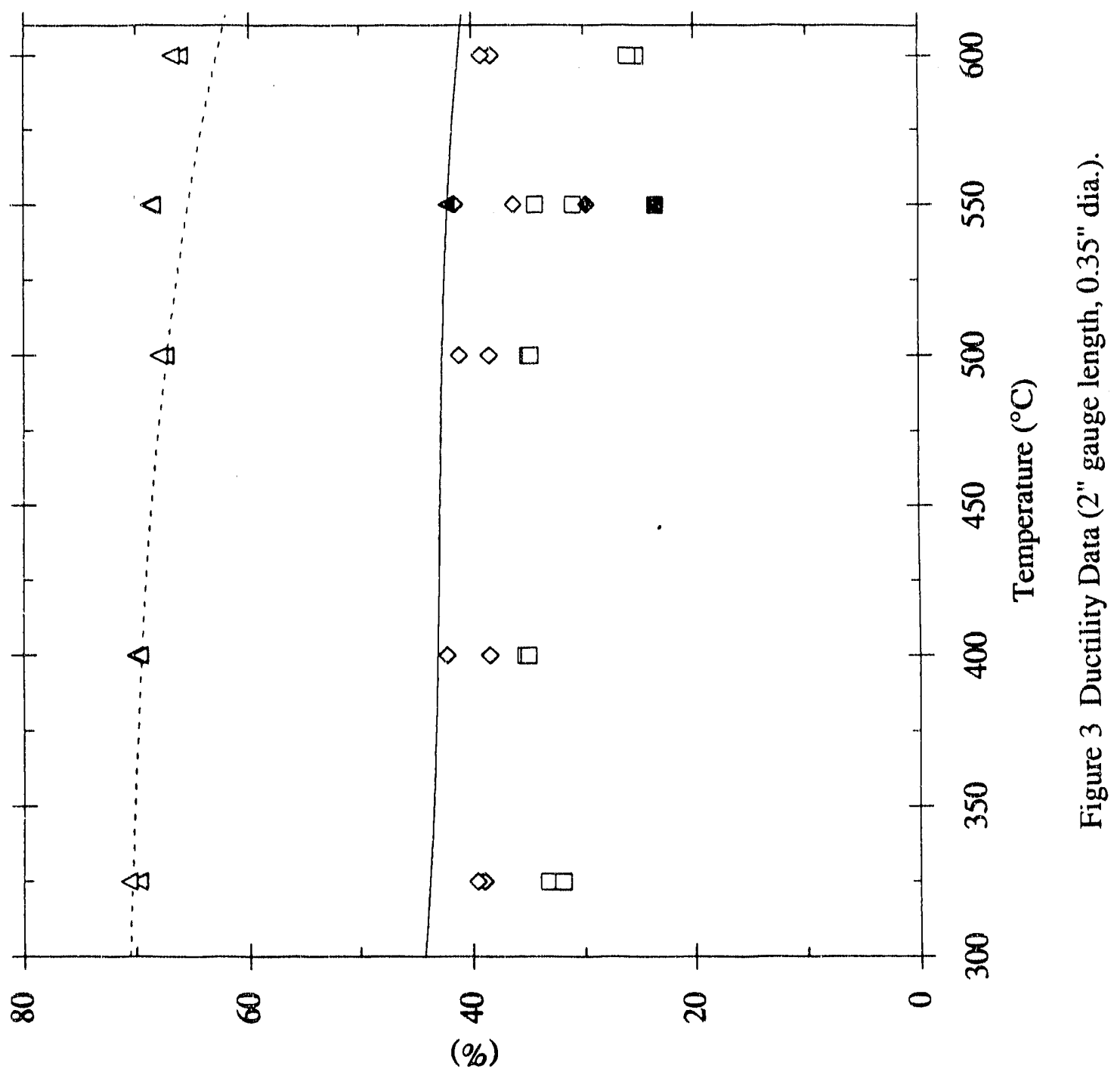




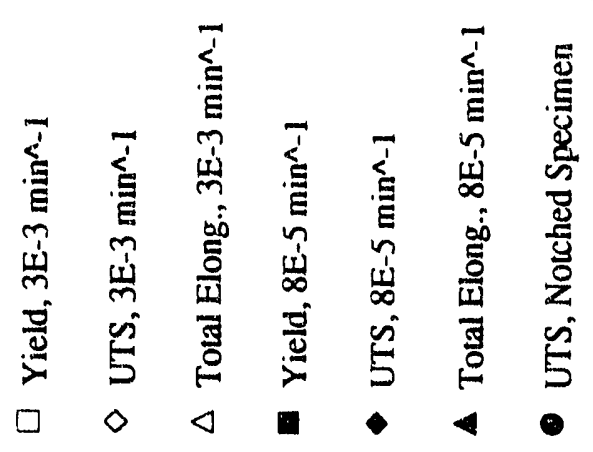

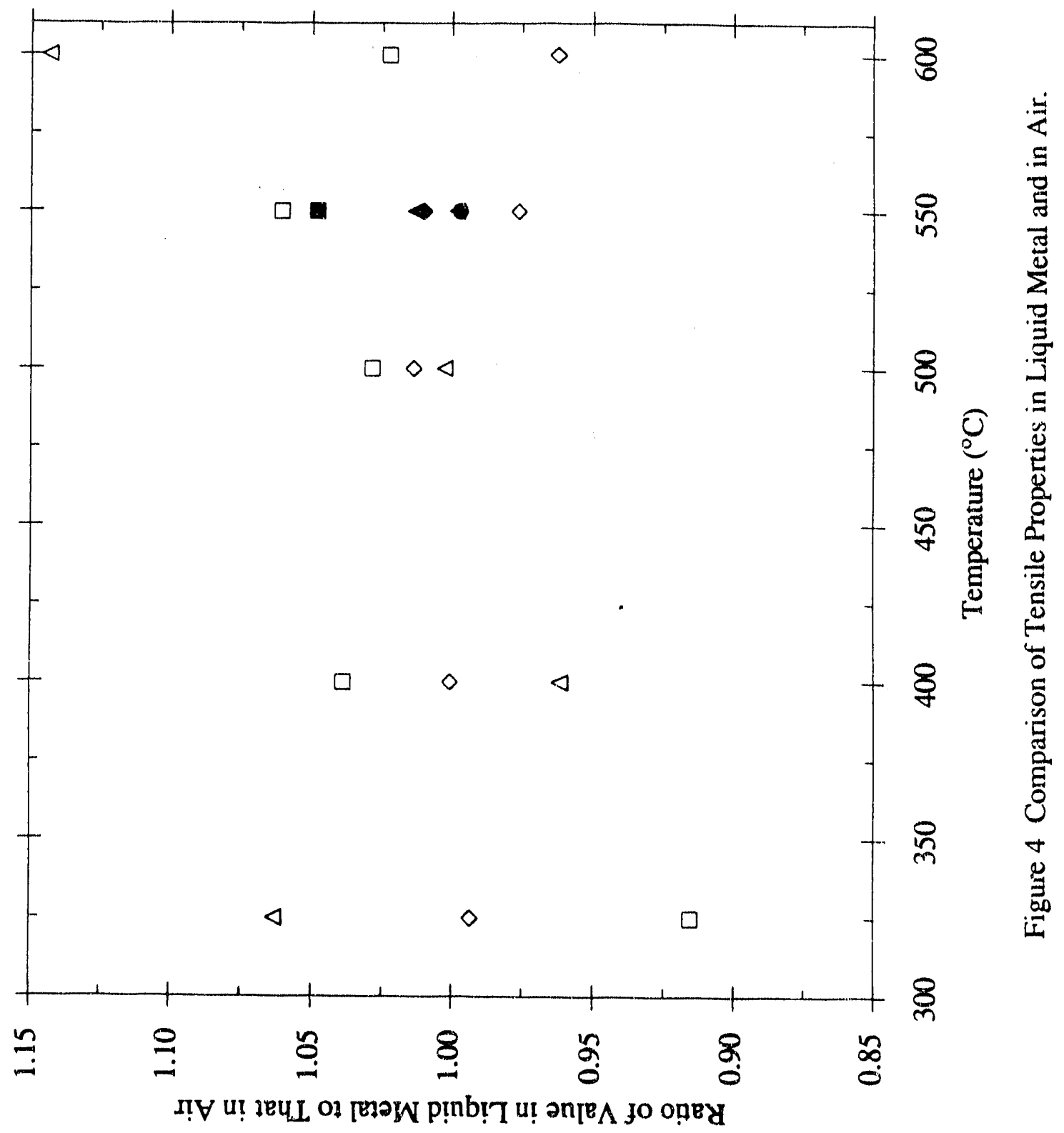




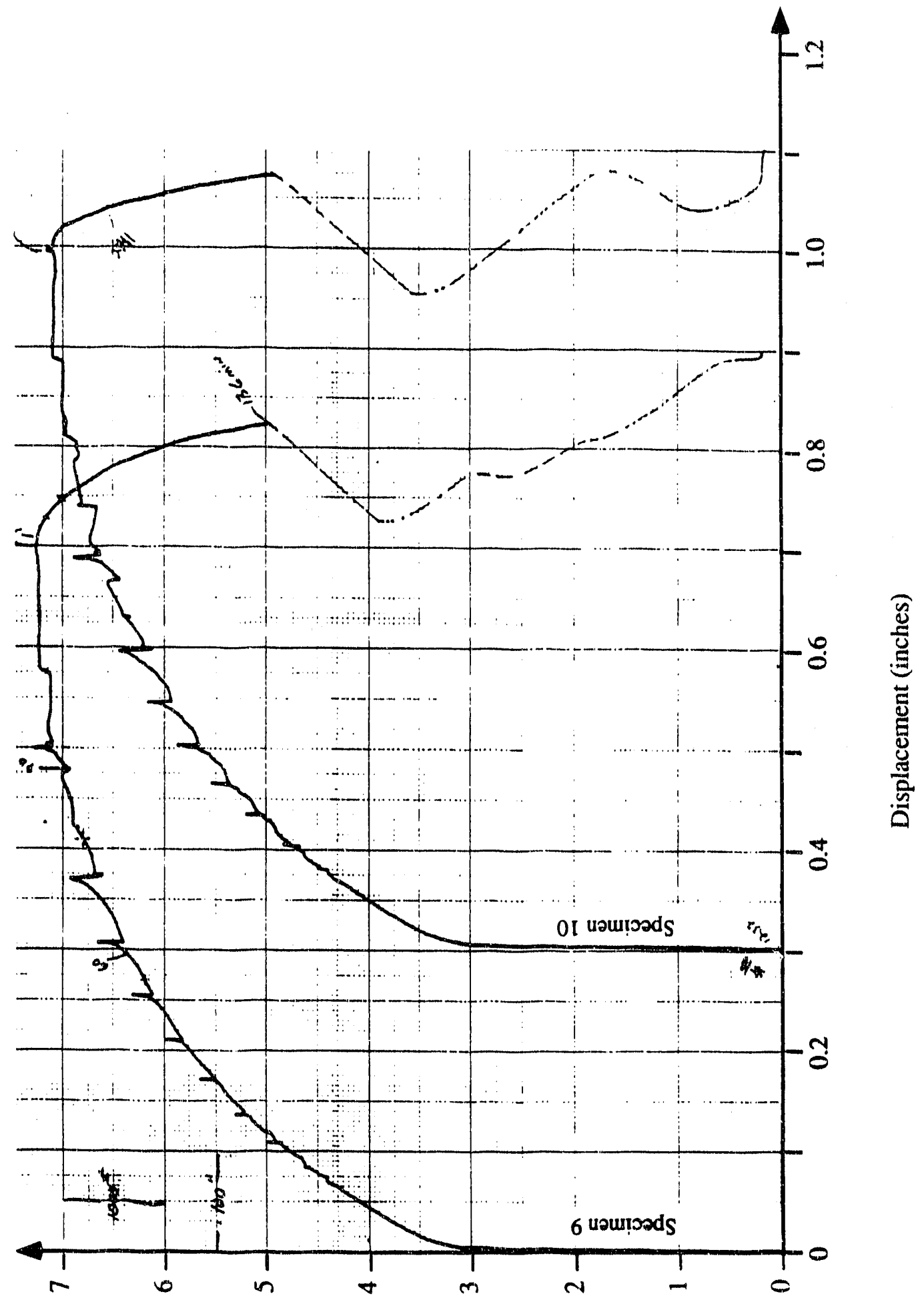

(sdp̣) prot

Figure 5 Load-Displacement Curve for Tensile Test in Air at $500^{\circ} \mathrm{C}$ and $3 \mathrm{E}-3 \mathrm{~min}^{-1}$. 


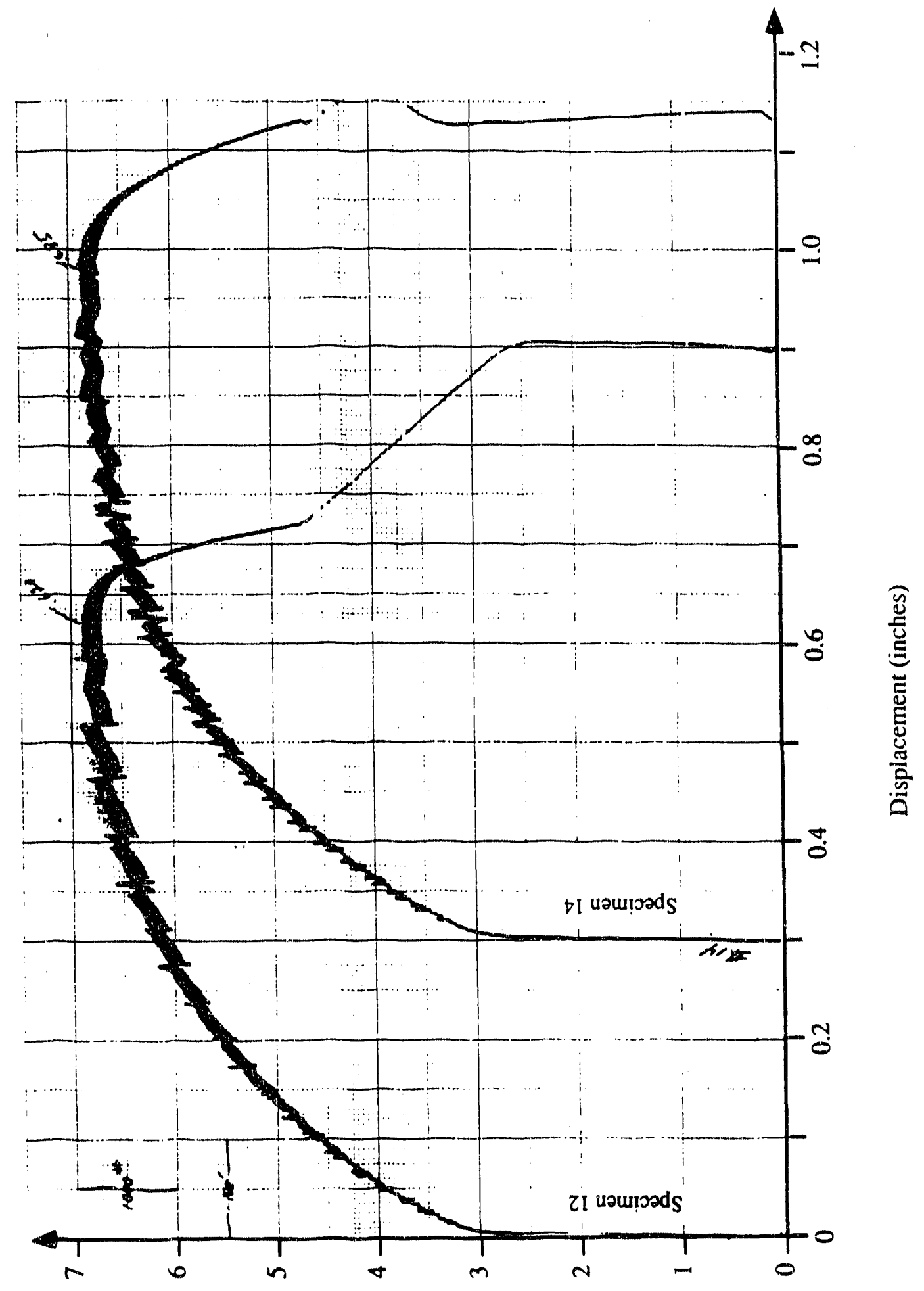

(sdpi) proot

Figure 6 Load-Displacement Curve for Tensile Test in Air at $550^{\circ} \mathrm{C}$ and $3 \mathrm{E}-3 \mathrm{~min}^{-1}$. 


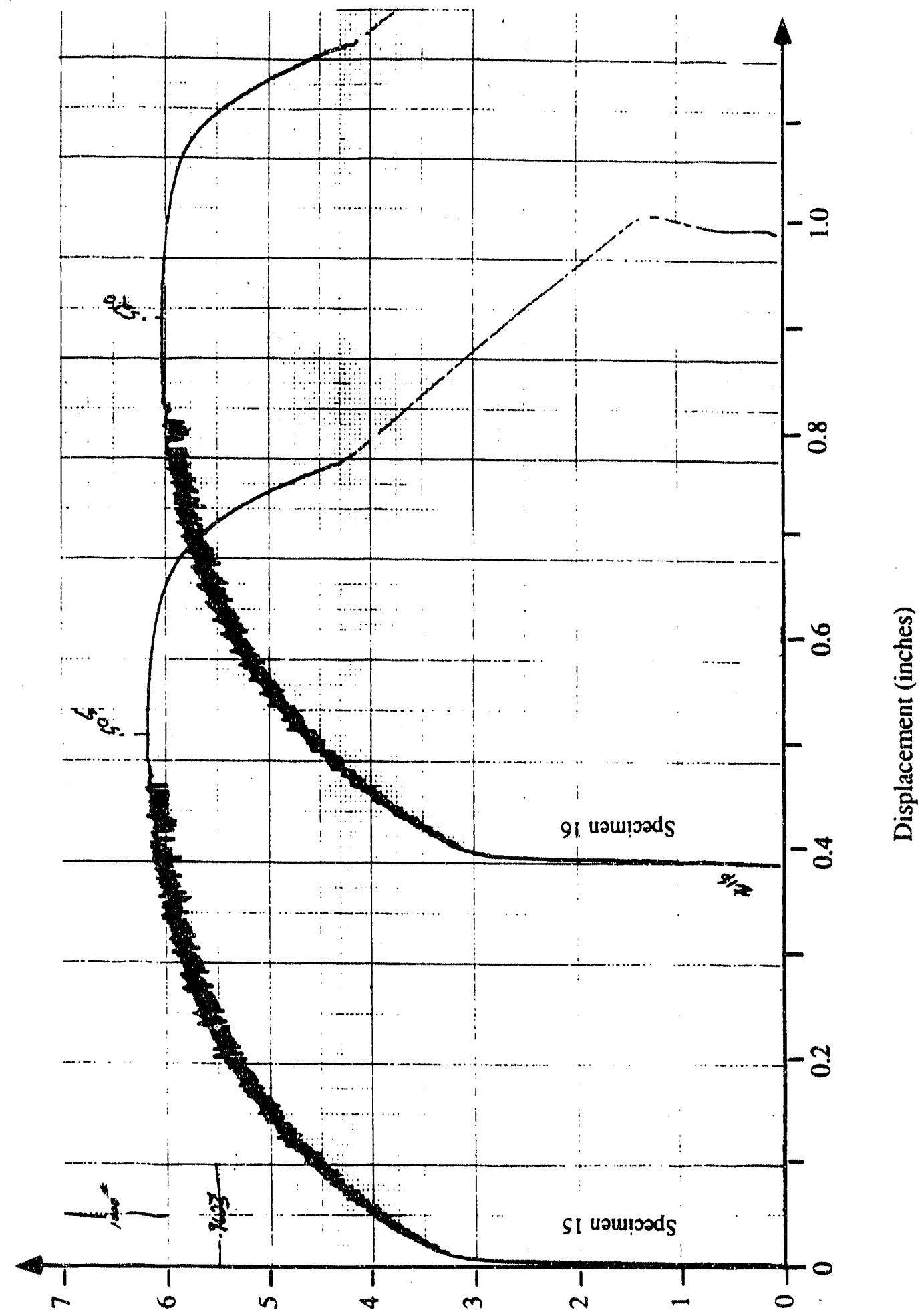

(sdp̣) prơ

Figure 7 Load-Displacement Curve for Tensile Test in Air at $600^{\circ} \mathrm{C}$ and 3E-3 min-1. 
Westinghouse

Electric Corporation

March 6, 1992
1310 Beulah Road

Pittsburgh. Pennsylvania 15235

(412) 2561000

\section{CTS-92-001}

\section{TENSIL AND BURST TESTS OF TYPE 304 STAINLESS STEEL}

Dr. K. Thomas

Westinghouse Savannah River Company

Savannah River Laboratory

Bldg. 773-41A

P. O. Box 616

Aiken, SC 29802

One of the postulated accident scenarios for a heavy water reactor results in the exposure of type 304 stainless steel tubing to both internal pressure and liquid cadmium. To aid in the analysis of this accident scenario, information was needed on the effect of liquid cadmium on the mechanical properties of Type 304 stainless steel with emphasis on the evaluation of the possibility of liquid metal embrittlement. At the request of the Savannah River Laboratory of the Westinghouse Savannah River Company, elevated temperature tensile tests of Type 304 stainless steel were conducted in both air and liquid cadmium. Several tubing burst tests were a!so conducted. This letter report provides formal transmittal of these laboratory test results. Following paragraphs provide descriptions of the test procedures and test results. Conclusions relative to the significance of this test data are also presented.

Two basic types of tests were conducted, standard tensile tests and tubing burst tests. Smooth bar tensile tests were conducted using threaded end specimens with a gage diameter of 0.350 inches and a 2.00 inch gage length. Several notched bar tensile tests were also performed. In these cases the unnotched diameter was 0.350 inches, the rotched diameter was 0.252 inches and the notch root radius was 0.007 inches. The test specimens were machined from 0.625 inch diameter annealed bar. The material certification lists ihe chemistry as:

$\begin{array}{lc}\mathrm{C} & 0.058 \\ \mathrm{Cr} & 18.32 \\ \mathrm{Ni} & 8.94 \\ \mathrm{Mn} & 1.78 \\ \mathrm{Si} & 0.52 \\ \mathrm{Mo} & 0.51 \\ \mathrm{Cu} & 0.40 \\ \mathrm{~S} & 0.14 \\ \mathrm{P} & 0.028 \\ \mathrm{~N} & 0.09 \\ \mathrm{Fe} & \text { balance }\end{array}$


CTS-92-001

Page 2

March 6, 1992

All but two of the tensile tests were conducted at a crosshead speed leading to a strain rate of $3 \mathrm{e}-3 / \mathrm{min}$. on the 2.0 inch gage length. The other two tests were conducted at a strain rate of $8 \mathrm{e}-5 / \mathrm{min}$. Load versus crosshead displacement curves were recorded for all tests. A gage length extensometer was used for the tests in air. Elongation values were obtained from the extensometer records and correlated with the cross head displacement records. Crosshead displacement records were used to calculate the elongation of specimens tested in cadmium using the correlation factors determined from the tests in air.

A furnace with three independently controlled zones led to a temperature control of $\pm 2^{\circ} \mathrm{C}$ at the test temperatures of $325^{\circ} \mathrm{C}, 400^{\circ} \mathrm{C}, 500^{\circ} \mathrm{C}, 550^{\circ} \mathrm{C}$ and $600^{\circ} \mathrm{C}$. For tests in cadmium liquid, a stainless steel cup on the bottom tensile grip held 35 grams of cadmium. In order to match the application of interest, a sleeve of aluminum alloy 6061 lined the inside of the stainless steel cup. The cadmium was molten at the test temperatures and was in coniact with the gage length of the tensile specimen at the center of this cup and in contact with the aluminum alloy on the inner diameter of the cup. A stainless steel muffle with $O$ ring seals for the pullrods contained the cadmium which vaporized in the liquid cadmium tests. This sealed muffle extended several inches beyond the furnace and had water cooled ends. A close fitting vent duct was placed to exhaust any possible release of fumes, although monitoring did not detect any release of cadmium vapor. Tests typically lasted 2 hours. Even with a cap on the top of the stainless steel cup a large vapor loss was noted. The cadmium vapor condensed on the cooler parts of the muffle and pullrod ascembly. A small solidified pool of cadmium was observed at the bottom of the stainless steel cup at the completion of the tests. The two tests at the slowest strain rate lasted several days. For these tests a stainless steel bellows was attached to either end of the tensile specimen. This effectively prevented any large loss of cadmium by vapor transport during the test.

Burst tests were conducted on Type 304 stainless steel tubing supplied by SRL. This tubing was archive safety rod cladding with a measured diameter of 0.940 inches and a wall thickness of 0.037 inches. One tube was pressurized to burst and the second tube was held at an internal pressure of 3480 psi for 6 hours. Both tests were conducted at $550^{\circ} \mathrm{C}$. A a two zone furnace was used to control the test temperature. The temperature distribution and end fitting design was checked out using a dummy specimen. The tube specimens were 9.5 inches in length. The central 6 inches of the specimens were maintained 
CTS-92-001

Page 3

March 6, 1992

at temperature to within $\approx 3^{\circ} \mathrm{C}$. Nitrogen gas controlled by a gas bottle regulator was used to supply the internal pressure. Pressure versus time and pressure versus diameter measurements were recorded autographically. Diameter measurements were accomplished by mounting a clip gage across the specimen diameter. Quartz rods contacted the specimen and extended outside of the furnace to contact the legs of the external clip gage. Tensile and burst test results are presented below.

Tensile test results are listed in Table 1. Values for ultimate strength and elongation are reasonably typical for Type 304 stainless steel. Yield strength levels are higher than expected for material certified as annealed at $1950^{\circ} \mathrm{F}$. Some cold work, probably from a straightening process, is the likely cause of the small increase in yield strength. A small degree of cold work is actually in better agreernent with the condition of the safety rod cladding which was cold worked a small amount on to the cadmium and aluminum core. There is no difference in the strength and ductility properties between tests in air and tests in cadmium. Tests at a very slow strain rate did reduce the elongation but this occurred in both air and cadmium environments. Figure 1 provides a graphic illustration of the eq'uivalent ductility is air and cadmium tests. Here the ratio of elongation of tests in the cadmium environment to tests in air is plotted versus temperature. This ratio is essentially unity. regardiess of the test temperature. No evidence of liquid metal embrittlement is evident.

One tube of Type 304 stainless steel was pressurized to burst at $550^{\circ} \mathrm{C}$. The total test duration was about 6 minutes. The rate of expansion of the tube diameter was roughly linear in time. Burst occurred at a pressure of 4200 psi. This was in accordance with expectations. The hoop strain at burst was $15.4 \%$ as measured from the pressure-diameter cliart. This parameter was $16.3 \%$ from post test measurement of the tube circumference. The deformed nature of the tube at burst made measurements difficult. The chart value of hoop strain at burst is considered more reliable. The second tube specimen was pressurized to 3480 osi at $550^{\circ} \mathrm{C}$. Upon pressurization a hoop strain of $3.4 \%$ developed. The pressure was maintained at 3480 psi for 6 hours. The increase in hoop strain during this time period due to time dependent deformation was less than $0.2 \%$. This is very small compared to the level required for burst. 


\section{CTS-92-001}

\section{Page 4}

March 6, 1992

Conclusions relative to the tensile and burst tests are relatively straightforward. There was no indication of liquid metal embrittlement of Type 304 stainless steel by cadmium. Tensile properties in air and liquid cadmium over the temperature range of $325^{\circ} \mathrm{C}$ to $600^{\circ} \mathrm{C}$ are essentially identical. The burst pressure of the Type 304 safety rod cladding at $550^{\circ} \mathrm{C}$ was $4200 \mathrm{psi}$ and hold time effects up to 6 hours will not substantially change the burst pressure.

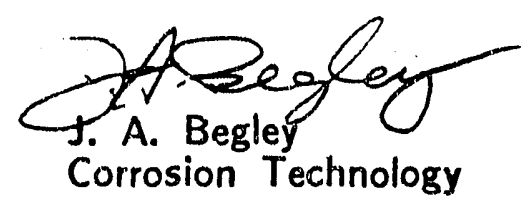

$J A B /$ maf

Attachments

cc: N. G. Awadalla, SRL

R. J. Jacko, STC 


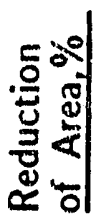

น

요요요

통 영

ก

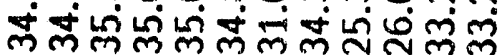

뭉

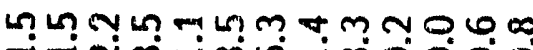

न

$\frac{5}{5} \frac{5}{5}$

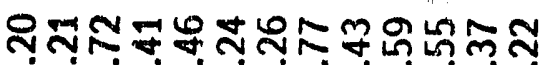

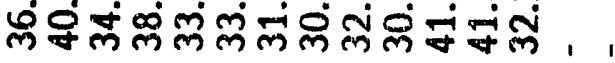

ㄸํํำ ำ ำ

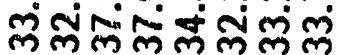

mं்

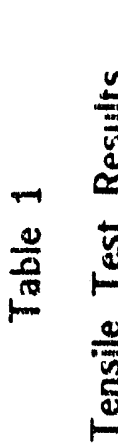

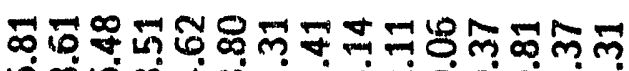

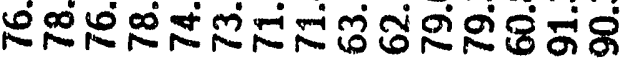

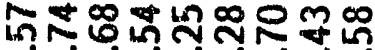

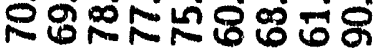

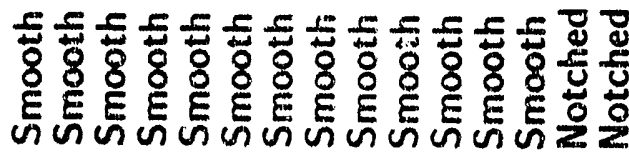

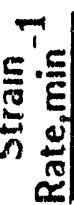

ชึ

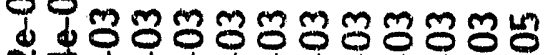

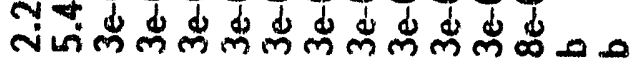

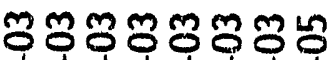

ले

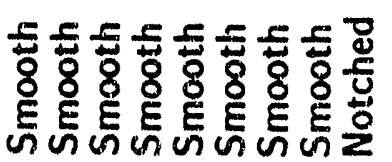

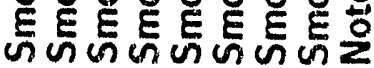

횡

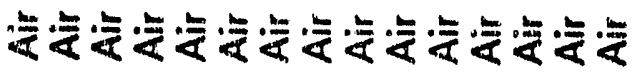

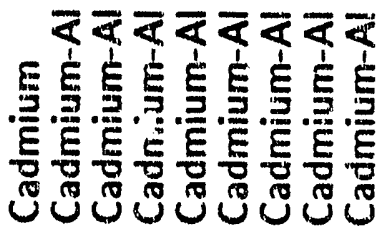

है

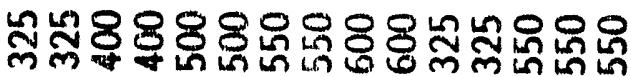

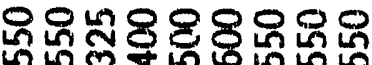

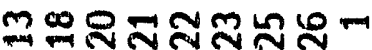

แ⿻

?

ชั

4

$\overline{0}$

$\frac{\mathscr{E}}{\mathscr{E}}$ 


\section{ATTACHMENT B}

\section{Portion of Workscope for Interworks Requisition 96472-0897742 \\ Dealing with Burst and Tensile Tests (Rev.1, 3/92)}

\subsection{WORK SCOPE FOR BURST AND TENSILE TESTS}

Westinghouse Savannah River Company (WSRC), through the Savi anah River Laboratory (SRL), is currently evaluating the time-temperature response of safety rod materials in support of the Reactor Restart Division. WS\&TC (J. A. Begley) is requested to provide the following experiments and evaluations in support of this evaluation:

\subsection{Type 304 Stainless Steel Tensile Tests}

These tests are intended to determine the susceptibility of SS304 to LME embrittlement by cadmium $(\mathrm{Cd})$ or cadmium-aluminum (Cd-Al) liquid metal solutions. Details of this evaluation are given below:

\section{(i) Test Conditions}

- The tests to be conducted are summarized in the table below.

\begin{tabular}{|c|c|c|c|c|c|}
\hline Test & $\begin{array}{c}\text { Temp. } \\
\left({ }^{\circ} \mathrm{C}\right)\end{array}$ & $\begin{array}{c}\text { Environ- } \\
\text { ment }\end{array}$ & $\begin{array}{l}\text { Strain Rate } \\
\qquad\left(\min ^{-1}\right)\end{array}$ & $\begin{array}{c}\text { Specimen } \\
\text { Type }\end{array}$ & $\begin{array}{l}\text { No. } \\
\text { Tests }\end{array}$ \\
\hline $\begin{array}{l}1 \\
2 \\
3 \\
4 \\
5 \\
6 \\
7 \\
8 \\
9 \mathrm{a} \\
9 \mathrm{~b} \\
10 \\
11 \\
12 \\
13 \\
14\end{array}$ & $\begin{array}{l}325 \\
400 \\
500 \\
550 \\
600 \\
325 \\
400 \\
500 \\
550 \\
550 \\
600 \\
550 \\
" 1 \\
" \\
"\end{array}$ & $\begin{array}{c}\text { Air } \\
" ~ \\
" \\
\text { Cd-Al } \\
\text { "Al } \\
\text { Cd } \\
\text { Cd-Al } \\
\text { Air } \\
\text { Cd-Al } \\
\text { Air } \\
\text { Cd-Al }\end{array}$ & $\begin{array}{c}\approx \underset{"}{3 \mathrm{E}-3} \\
" \\
" \\
" \\
" \\
" \\
" \\
" \\
" \\
\approx \\
=8 \mathrm{E}-5\end{array}$ & $\begin{array}{c}\text { Smooth } \\
" \\
" \\
" \\
" \\
" \\
" \\
" \\
" \\
" \\
\text { Notched } \\
\text { Smooth } \\
\text { Smed }\end{array}$ & $\begin{array}{l}2 \\
" \\
" \\
" \\
" \\
1 \\
" \\
" \\
\text { " } \\
\text { " } \\
2 \\
1 \\
"\end{array}$ \\
\hline
\end{tabular}


- An air environment may be employed in the oven employed to heat the test specimens to the desired temperature.

- Two specimens are to be used for each test in air at a strain rate of $3 E-3 \mathrm{~min}^{-1}$ (total of 21 specimens).

\section{(ii) Test Specimens and Equipment}

- STC will provide the test specimens all other hardware necessary to conduct the tests.

- Standard 0.350 inch diameter tensile specimens composed of Type 304 stainless steel should be employed. The specimens are to be manufactured from mill annealed bar stock.

- For the test to be conducted in $\mathrm{Cd}$ or $\mathrm{Cd}-\mathrm{Al}$, this may be accomplished by encapsulating pieces of $\mathrm{Cd}$ or $(\mathrm{Cd}$ and $\mathrm{Al})$ with the specimen. Other techniques which ensure the desired liquid metal solution is kept in contact with the specimen surface throughout the test will also be acceptable

- The specimens may be heated using a muffle furnace.

\section{(iii) Data Monitoring and Acquisition}

- The load and crosshead displacement should be recorded throughout the test in order to construct a standard stress-strain curve.

- All measuring equipment employed must be calibrated; the calibration records are to te provided to SRL as part of the deliverables package.

\section{(iv) Documentation}

- A letter report should be provided which describes the experiments and results. Standard tensile properties (e.g. elastic properties, yield strength, ultimate strength, elongation at failure, uniform elongation) should be reported for all tests.

- In addition to (or as part of) the letter report, the following documentation should be transmitted to SRL: all raw data (stress-strain curves), copies of calibration records for measurement devices, photographs of the test set up, and any other information deemed relevant by STC. 


\subsection{Pressurized Cladding Burst Tests}

These tests are intended to illustrate the response of the safety rod cladding to a pure mechanical overpressure in the absence of environmental interaction. Two pressurized cladding burst tests are to conducted using sections of cladding supplied by SRL. Details of this evaluation are given below:

\section{(i) Test Conditions}

- Test temperature should be $550^{\circ} \mathrm{C}$.

- An inert gas should be employed as the pressurizing medium. Argon gas is acceptable for this purpose.

- The first test is to be conducted by increasing the cladding internal pressure monotonically until failure (cladding rupture) occurs. The rate of pressure increase should be such that failure occurs within 30 minutes of test initiation.

- The first test is to be conducted by pressurizing the cladding to approximately $80 \%$ of the burst pressure from the first test and holding at pressure for 6 hours.

\section{(ii) Test Specimens and Equipment}

- SRL will provide the safety rod cladding sections to be tested. The cladding is made of Type 304 stainless steel and is approximately 37 mils thick and has a 0.94 " suter diimeter.

- STC will provide all other hardware necessary to conduct the tests.

\section{(iii) Data Monitor ing and Acquisition}

- The cladding diameter and test pressure are to be recorded throughout the test.

- All measuring equipment employed must be calibrated; the calibration records are to be provided to SRL as part of the deliverables package.

\section{(iv) Documentation}

- A letter report should be provided which describes the experiments and results.

- In addition to (or as part of) the letter report, the following documentation should be transmitted to SRL: all raw data (pressure and cladding diameter as a function of time), copies of calibration records for measurement devices, photographs of the test set up, and any other information deemed relevant by STC. 


\subsection{DELIVERABLES}

\subsubsection{Technical Reports:}

The experiments identified in this work scope shall be documented in a brief letter report; the minimum content of these reports was given above. The report will be issued within 2 weeks after completion of the the tests.

The work contained in this work scope will complernent in-house work in support of critical applications. Hence all work shall be in accordance with (W) Q/A procedures, if such procedures exist and are employed at WSTC. In absence of such formal procedures, the following minimum requirements will be met:

- all measurement equipment shall be calibrated.

- all documentation relative to the tests shall be retained; these are to be delivered to

SRL at the conclusion of the work.

The test specimens employed for both the tensile and pressurized cladding tests are to be returned to SRL at the completion of the work so that more detailed examinations may be conducted.

\subsection{CONTACTS}

Jim Begley will be the STC program coordinator. The contacts for this task and the recipients for the draft and final letter reports at Westinghouse Savannah River Company, Savannah River Laboratory are:

Kelly Thomas (803) 725-2922

Natraj lyer (803) $725-2695$

Bill Awadalla (803) 725-3850

\subsection{SCHEDULE}

The burst and tensile test experiments will be completed within six months following initiation of the experiments. A report documenting the experiments and results will be delivered to SRL within two weeks following completion of the experiments. 

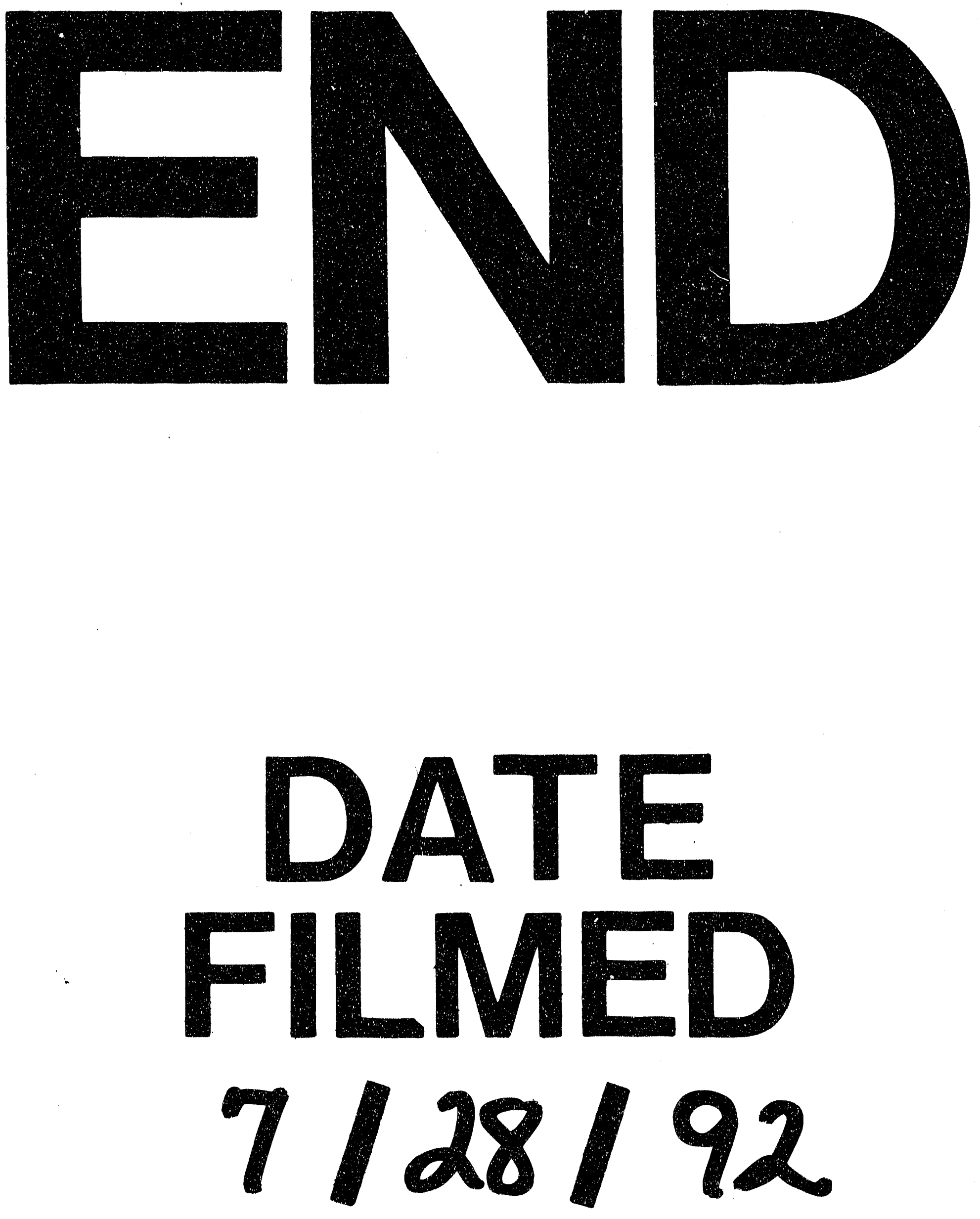


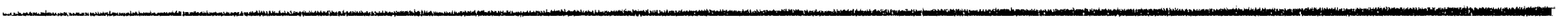

